\title{
Ecology of endolithic lichens colonizing granite in continental Antarctica
}

\author{
Asunción DE LOS RÍOS, Jacek WIERZCHOS, Leopoldo G. SANCHO, \\ Allan GREEN and Carmen ASCASO
}

\begin{abstract}
In this study, the symbiont cells of several endolithic lichens colonizing granite in continental Antarctica and the relationships they have with the abiotic environment were analyzed in situ, in order to characterize the microecosystems integrating these lichens, from a microecological perspective. Mycobiont and photobiont cells, the majority classified as living by fluoresecent vitality testing, were observed distributed through the fissures of the granite. The fact that extracellular polymeric substances were commonly observed close to these cells and the features of these compounds, suggest a certain protective role for these substances against the harsh conditions of the environment. Different chemical, physical and biological relationships take place within the endolithic biofilms where the lichens are found, possibly affecting also the survival and distribution of these organisms. The alteration of bedrock minerals and synthesis of biominerals in the proximity of these lichens gives rise to different chemical microenvironments and suggests their participation in mineral nutrient cycling.
\end{abstract}

Key words: Antarctica, endoliths, EPS, lichens, microecology, mineral-lichen interactions

\section{Introduction}

The Antarctic continent is the coldest, driest, windiest and most isolated landmass on Earth, yet despite these harsh conditions, there is still substantial terrestrial vegetation (Robinson et al. 2003). As part of this vegetation, many lichen species are components of lithobiontic communities (Seppelt et al. 1995; Castello \& Nimis 1997; Øvstedal \& Lewis Smith 2001). Some of these lichens can withstand extreme environmental conditions and live on the surface of rocks. However, others appear to avoid these conditions by colonizing the inside of lithic substrata (Wierzchos \& Ascaso 2001; Ascaso

A. de los Ríos and C. Ascaso: Centro de Ciencias Medioambientales (CSIC), Serrano 115 bis, 28006 Madrid, Spain.

J. Wierzchos: Servei de Microscopia Electronica, UdL, Rovira Roure 44, Lleida, Spain.

L. G. Sancho: Biologia Vegetal II, Universidad Complutense de Madrid, 28040 Madrid, Spain.

A. Green: Biological Sciences, Waikato University, Hamilton, New Zealand.
\& Wierzchos 2003; De los Ríos et al. 2005). Thus, we can find microbial life in areas where the environmental conditions preclude the colonization of rock surfaces (Friedmann 1982; Green et al. 1999).

The study of lithobiontic microorganisms in general, and endolithic lichens in particular, has met with numerous difficulties. The symbionts of the latter are not only hidden in the hard lithic substratum but their most important interactions are those established with their immediate physical environment, i.e. the lithic substratum. Hence endolithic lichens require analyses on a microecological scale, for which the approaches normally used for ecological studies on epilithic lichens are inappropriate. The physical organization of lichen symbiont cells within local lithic microenvironments and interrelations between these and the surrounding environment must be analysed from a microecological perspective. Microscopy is an ideal technique for such studies, especially when applied in situ, that is, when the biological components are not separated from 
the lithic material (Ascaso \& Wierzchos 2003; De los Ríos et al. 2005). Using this technique, the zone of the lithic substratum colonized by lichens is seen as complex organic-mineral interfaces composed of a range of microorganisms, the organic compounds generated by them, together with inorganic materials. At these interfaces, lichenized algae and fungi, sometimes with free-living microorganisms, are organized as biofilms (De los Ríos et al. 2002). The suite of microorganisms comprising these biofilms and their biotopes where different interrelationships are established, constitute a tiny ecosystem or microecosystem (De los Ríos et al. 2003). In the present study, we have used in situ microscopy techniques to characterize both the biological and abiotic components of microecosystems integrating endolithic lichens from two sites in continental Antarctica, and examined the interactions occurring in the system on a microecological scale. This work forms part of our ongoing project designed to characterize different ecological aspects of endolithic lichens in an effort to improve our understanding of how these lithic microecosystems function.

\section{Materials and Methods}

\section{Materials}

Fragments of granite rock were collected from several sites near Canada Glacier Taylor Valley (Dry Valleys, $\left.77^{\circ} 37^{\prime} \mathrm{S} 162^{\circ} 59^{\prime} \mathrm{E}\right)$ and Cape Geology, Granite Harbour (Ross Sea coast $77^{\circ} 00^{\prime} \mathrm{S} 162^{\circ} 00^{\prime} \mathrm{E}$ ). Rock samples, $0 \cdot 5-1 \mathrm{~cm}$ thick, with visible signs of endolithic microbial growth were placed in sterile polyethylene bags, transported by air to our laboratory and stored dry at $-20^{\circ} \mathrm{C}$ until processing.

\section{Transmission electron microscopy examination}

Fragments of endolithic biofilm were removed from the rock under the stereomicroscope using a sterile needle and embedded in $2 \%(\mathrm{w} / \mathrm{v})$ agar. Small pieces of agar containing the microbial cells were then immediately fixed in glutaraldehyde and osmium tetroxide solutions, dehydrated in a graded ethanol series, and embedded in Spurr's resin following the protocol described in De los Ríos \& Ascaso (2001). Ultrathin sections were post-stained with lead citrate (Reynolds 1963) and observed in a Zeiss EM910 transmission electron microscope (TEM).

\section{Scanning Electron Microscopy}

\section{Low Temperature}

Fragments of rock colonized by lichens were examined using Low Temperature Scanning Electron Microscopy (LTSEM). Small fragments were mounted using O.C.T. compound (Gurr) and mechanically fixed onto the specimen holder of the cryotransfer system (Oxford CT1500). These samples were plunge-frozen in subcooled liquid nitrogen and then transferred to the preparation unit. The frozen specimens were cryofractured and etched for $2 \mathrm{~min}$ at $-90^{\circ} \mathrm{C}$. After ice sublimation, the etched surfaces were gold sputter coated and the specimens then placed on the cold stage of the SEM chamber. Fractured surfaces were observed under a DSM960 Zeiss SEM microscope at $-135^{\circ} \mathrm{C}$ under conditions of a $15 \mathrm{kV}$ acceleration potential, $10 \mathrm{~mm}$ working distance and 5-10 nA probe current.

\section{Back-Scattered Electron Mode and Energy Dispersive} $X$-ray Spectroscopy

Fragments of granite colonized by endolithic lichens were processed for scanning electron microscopy with backscattered electron imaging (SEM-BSE) and/or energy dispersive X-ray spectroscopy (EDS) analysis according to a method described by Wierzchos and Ascaso (1994). The fragments, after fixing and dehydration in an ethanol series, were embedded in LR-White resin. Transverse sections of polished surfaces of the rock were examined using a DSM 960 A Zeiss microscope.

\section{Confocal Scanning Laser Microscopy}

For Confocal Scanning Laser Microscopy (CSLM), the rock samples were prepared according to a procedure based on the glutaraldehyde-enhanced fluorescence method used for plant tissues (Wierzchos \& Ascaso 2001). In brief, the samples were first fixed in glutaraldehyde, dehydrated in a graded series of ethanol solutions, and embedded in LR-White resin. Blocks of resin-embedded rock samples were cut transversally, finely polished and observed using an LSM 310 Zeiss confocal microscope.

\section{Fluorescence labelling}

Fluorescence assays were performed on fresh pieces of rock containing endolithic lichens. The LIVE/DEAD BacLight Kit L-13152 (Molecular Probes) was used to distinguish living and dead symbiont cells following the method described in Wierzchos et al. (2004). This kit contains two proprietary nucleic acid stains that differ in their ability to penetrate bacterial cell membranes. The green fluorescence nucleic acid stain, SYTO 9, labels all cells and the red fluorescence nucleic acid stain, propidium iodide, only penetrates cells with damaged membranes and quenches the green SYTO 9 stain. After fluorescence staining, the samples were processed for CSLM examination. They were fixed in paraformaldehyde, dehydrated in a graded ethanol series, and embedded in LR-White resin. The fluorescence intensity of living and dead microorganisms was then 

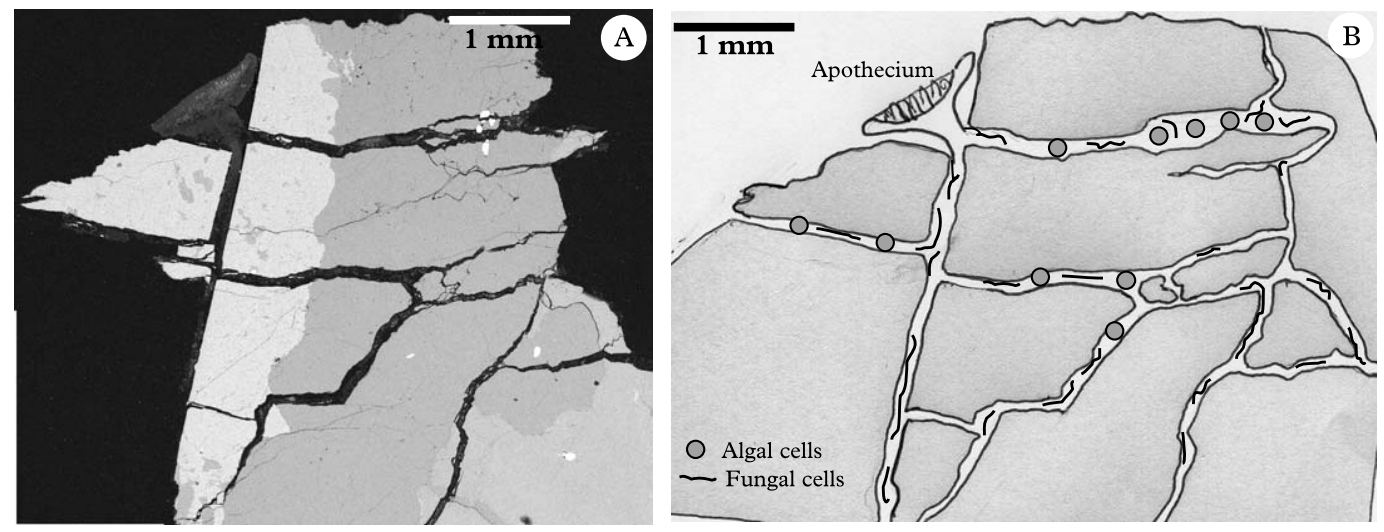

FIG. 1. Distribution of endolithic lichen symbiont cells and their structures through the fissures. A, SEM-BSE image of a rock colonized by Lecidea sp.: B, Model diagram corresponding to the area in Fig. 1A.

determined by CSLM double-channel scanning using an excitation wavelength of $488 \mathrm{~nm}$. SYTO 9 (green fluorescent dye) fluorescence intensity was measured at emission wavelengths between $515-545 \mathrm{~nm}$ for the detection of living microorganisms, and fluorescence intensity generated by propidium iodide was measured at emission wavelengths longer than $570 \mathrm{~nm}$ to detect dead microorganisms. Each channel was displayed in a single colour (green and red respectively) and the images were superimposed using the Adobe Photoshop program. In the final image, cells with intact cell membranes were stained only green whereas cells with damaged membranes had red nuclei.

\section{Results}

\section{Endolithic biota colonizing Antarctic granite}

The endolithic microecosystems of Granite Harbour and the Dry Valleys materials examined contained many different microorganisms. In some samples, the symbionts of endolithic lichens constituted the predominant biota. These lichen dominated endolithic zones coincided with the presence of epilithic lichens or areas where the fruiting bodies of endolithic lichens occurred (Fig. 1A). Figure 1B provides a diagram of how the algal and fungal cells are distributed through the fissures of the granite. The association observed between fungal and algal cells (Fig. 2A), as well as the connection in several cases with identified external fruiting bodies allows the identification of lichen symbiont cells. Cyanobacteria were also observed but these occupied different zones within the rocks and were not observed close to the lichens. Heterotrophic bacteria were frequently observed in cyanobacterium-rich communities but were less common around endolithic lichen symbionts.

Most lichenized algal and fungal cells in these endolithic habitats appeared embedded in a polymeric matrix. Figure $2 \mathrm{~B}$ shows an endolithic mycobiont cell with numerous vacuoles within a thick extracellular layer (arrows). Extracellular polymeric substances (EPS) were detected around the different microorganisms forming the biofilm. The image in Figure 2C, obtained by LTSEM, shows the polymeric nature of the extracellular compounds (arrows) associated with mycobiont cells at the interface between an epilithic lichen thallus and the lithic substratum. These EPS produced by epilithic lichens extended as far as the endolithic biofilms observed in nearby fissures (arrow in Fig. 2D).

Several colonized fissures in granite from both geographical areas were seen to be fully occupied by lichenized algal and fungal cells (Figs $2 \mathrm{~A} \& 3 \mathrm{~A}$ ). Figure $3 \mathrm{~A}$ is a $3-\mathrm{D}$ image obtained by CSLM showing the spatial arrangement of endoliths in different fissures of a rock sample from Canada Glacier. Mycobiont cells were present in all fissures occupied by the lichen (Fig. 3B), even very narrow fissures (Fig. 3C), but algal cells 

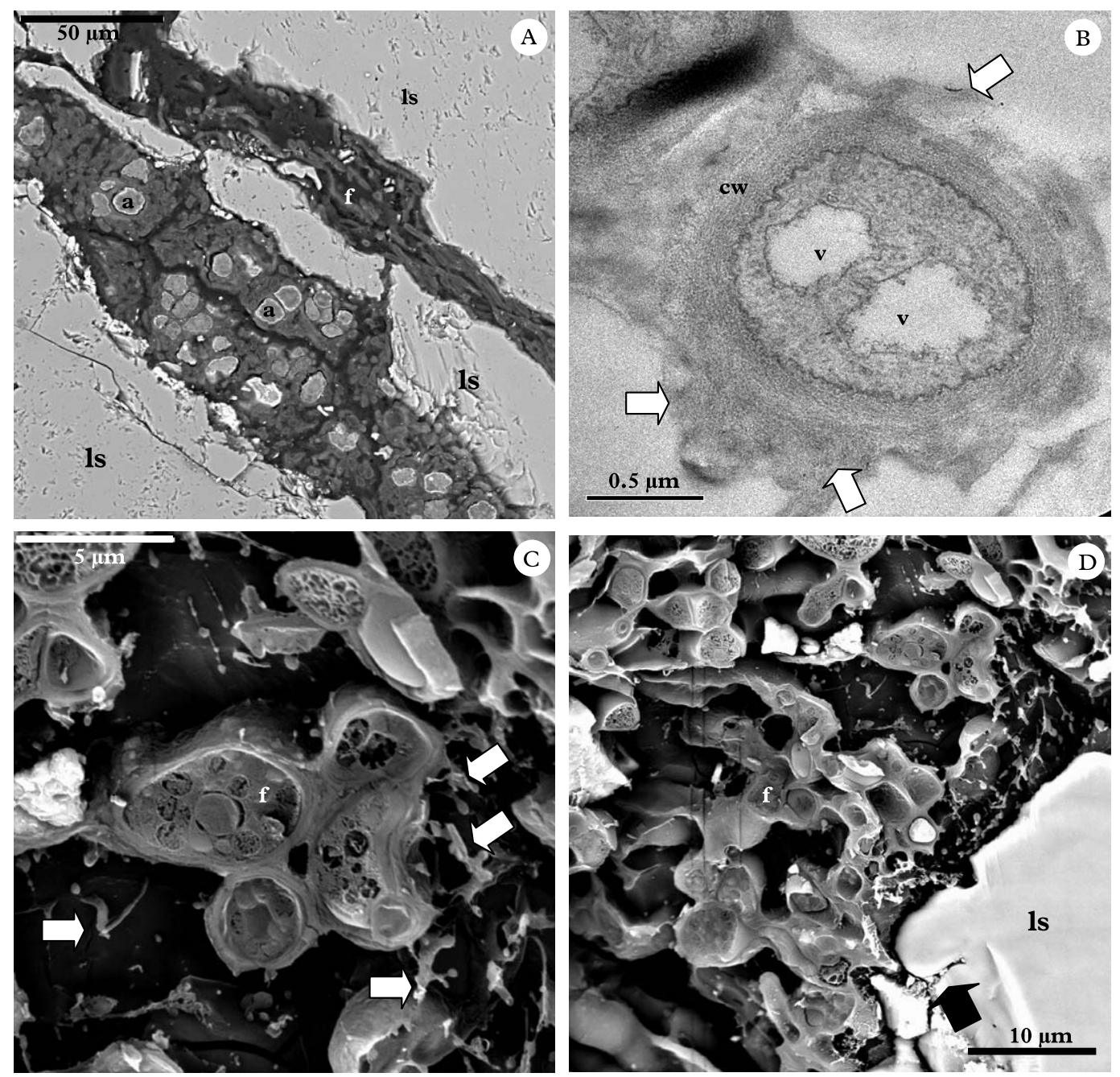

FIG. 2. Lichen symbiont cells colonizing Antarctic granite. A, SEM-BSE image of a transverse section of granite from Granite Harbour showing the endolithic colonization of Lecidea cancriformis (a, algal cells; f, fungal cells; ls, lithic substratum); B, TEM image of an EPS-covered endolithic mycobiont cell of a non-identified lichen from the Taylor Valley, arrows point to an EPS cover ( $\mathrm{v}$, vacuoles; cw, cell wall); C, LTSEM image of mycobiont cells of a Buellia frigida thallus from Granite Harbour, arrows indicate EPS; D, LTSEM image of the interface between a Buellia frigida thallus and the lithic substratum, arrow indicates a fissure in the lithic substratum containing EPS.

were only detected in some sites and were more commonly observed in zones closest to the surface (Fig. 3D) than in the deeper rock areas (Fig. 3A).

The use of the BacLight Kit revealed living hyphae intermixed with dead or injured hyphal cells in several zones of the lithic substratum (Fig. 3E). In some zones, $95-100 \%$ of the cells were alive (green hy- phae without red stained nuclei) but within some fissures of the substratum, we were also able to distinguish areas in which 20$30 \%$ of the fungal hyphae were dead (green hyphae with red nuclei in Fig. 3E). Both living and dead photobiont cells were also detected in an endolithic lichen inside the lithic substratum where the nuclei of only a few Trebouxia cells stained red (red arrows), 
indicating the damaged-membrane state of the cells (Fig. 3F).

\section{Mineral components of biofilms containing endolithic lichens}

Mineral components mixed with the lichen cells were observed in the fissures and cavities within the rock substratum. Sometimes it was difficult to distinguish between the part of a fissure occupied by mycobiont cells and that filled with mineral fragments (Fig. 4A). Aluminiosilicate minerals were found to be especially closely associated with fungal cells (arrows in Fig. 4B). The element distribution map obtained by EDS analysis indicates that the minerals observed in the proximity of the cells were fairly heterogeneous (Fig. 4C-H). Both closely associated fine mineral fragments composed of iron and magnesium and larger mineral fragments rich in aluminium and silicon were observed. Aluminiosilicate fragments could be the result of physical weathering of fissure walls but the source of the finely disrupted minerals is unclear.

At the bottom of the Dry Valleys, living endolithic lichens are scarce (Green et al., 1999) but their previous occurrence was evidenced by the finding of mineralized remains (fossils) of lichens (Fig. 5A), which comprise recognizable mineralized structures such as algal and fungal cells.

\section{Relationships established between components of endolithic microecosystems}

The relationships within the analyzed living lichen communities seemed to be extremely diverse. For instance, in Figure 5B, the growth of an epilithic thallus of Buellia frigida is seen to give rise to several different endolithic microhabitats where other microorganisms thrive. Figure $5 \mathrm{C}$ is an enlargment of the area indicated with a square in Fig. 5B where bacteria are observed intermixed with fungal cells. Many of the microorganisms were intimately linked to their rock substratum generating complex mineral-microbe interactions, such that the lithic substratum was highly altered in the proximity of different Antarctic endolithic lichens (Fig. 2A, 5D). Figure 5D clearly shows the detachment and separation of mica minerals. Penetration by fungal hyphae was also observed in fissures in feldspar (arrows in Fig. 3B and Fig. 3C). Physical weathering by endolithic lichens was also frequently associated with a biogeochemical action, and evidence of the biomobilization of different elements and biomineralization processes could be observed around the organisms. Figure 5E shows a cavity occupied by mycobiont cells of Lecidea cancriformis, with a mineral deposit visible at the base of the cavity (m). Calcium and silicon distribution maps obtained by EDS revealed a large amount of calcium in the mineral deposits observed within the cavity in contrast to the silicon composition of the substratum (feldspar plagioclase). Thus, these deposits could be identified as calcium oxalate biominerals. In the lithic substratum, zones with small amounts of calcium can be detected (indicated by asterisks in Fig. 5E) reflecting intense calcium depletion in this feldspar plagioclase in an area close to thalli of Lecidea cancriformis (low-calcium zone indicated by asterisks). This biomobilization was clearly related to a biomineralization process, as indicated by the extensive calcium oxalate deposits in the cavity colonized by $L$. cancriformis.

\section{Discussion}

We have shown that endolithic lichens are components of endolithic biofilms, where close chemical, physical and biological relationships are established among symbiont cells and their immediate environment. It was not usually possible to identify clearly differentiated thallus layers in these endolithic lichens, although a degree of organization of the algal and fungal cells was observed. Endolithic lichens colonizing Beacon sandstones occupy the airspaces of the rock and do not form an organized thallus (Friedmann 1982). The distribution patterns shown by the symbiont cells in the present study were similar in granite from the extremely dry Canada Glacier site on the 

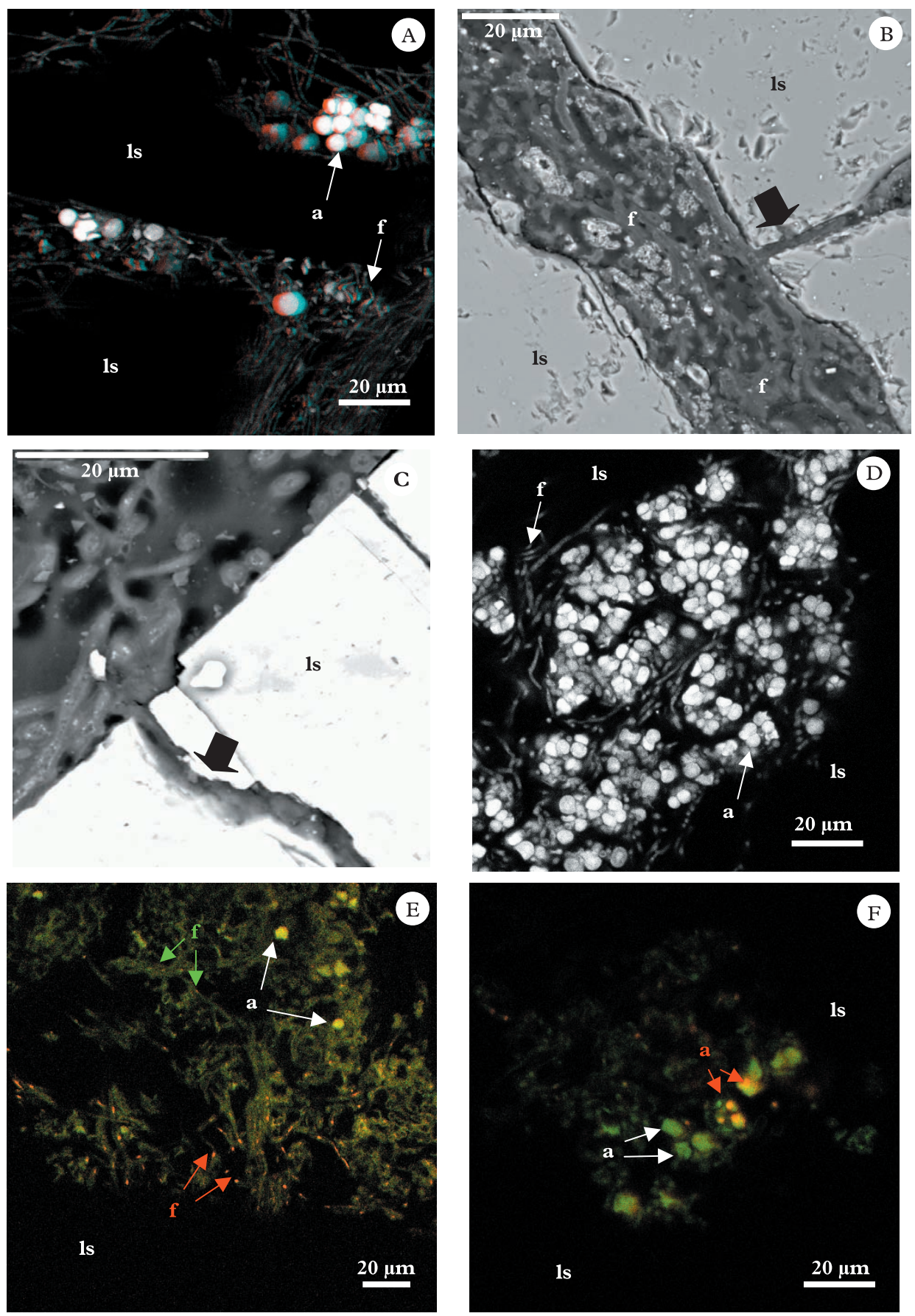
floor of Taylor Valley and the more equable granites at Granite Harbour on the Ross Sea coast. This suggests that the distribution of symbiont cells in the fissures and cracks of the granite is not determined solely by the external environmental conditions, but also by factors differing on a small spatial scale such as the physico-chemical features of the rock (Matthes et al. 2001; De los Ríos et al. 2005). Different ecological niches can be attributed to the different habitats occupied by endolithic lichens: cells of chasmoendolithic lichens colonize the fissures of the substratum, cryptoendolithic forms colonize its cavities and euendolithic ones actively penetrating the rock (Golubic et al., 1981). To a large extent the type of rock determines the microbial ecological niche. In the granite analysed here, the predominant ecological niche was chasmoendolithic (Fig. 1), whereas the higher porosity of sandstone promotes the presence of cryptoendolithic forms in other lichen dominated communities of the Ross desert (Friedmann 1982).

The endolithic environment appeared to be altered by the activity of the microbial cells. Several mineral-lichen interactions were observed in the form of geophysical and geochemical effects. Fungi were the biological components that produced the most intense geophysical weathering of the rocks, and mica was the mineral most susceptible to this bioalteration; for example mica minerals become more modifed than feldspar and quartz. Fungi not only participate in the alteration processes because of their physiological properties, but they also exert mechanical forces because of their ability to penetrate and spread through hard substrata (Sterflinger 2000) and due to their water binding capacity causing volume changes in wet and dry periods (De los Ríos et al., 1999). The ability of epilithic lichen thalli to disaggregate the rock surface has been frequently described (Banfield et al. 1999; Aghamiri \& Schwatzman 2002; Bjelland \& Thorseth 2002; De los Ríos et al. 2002). However, the real extent of the weathering capacity of endolithic lichens has yet to be fully evaluated. Although fungal action is probably not the only cause of the fissure formation, the images obtained during this study suggest that fungal penetration of granite could contribute to fissure formation and certainly be involved in subsequent widening of the fissure. The colonization of fissures by fungal cells, as observed here, and the growth of apothecia at the surface (De los Ríos et al. 2005), can have dramatic biogeophysical effects on granite rocks.

The present work has found compelling evidence that endolithic lichens are involved in biogeochemical processes occurring in granite. Biogeochemical processes prevail in the early stages of lichenization (Cooks \& Otto 1990) and these may be similar in the endolithic lichens examined here, in which it was not possible to distinguish welldifferentiated lichen thallus layers. Calcium biomobilization related to Antarctic endolithic lichens was observed in the present study, and potassium mobilization in biotites and feldspar has also been recently ascribed to endolithic Antarctic lichens (De los Ríos et al. 2005). In addition to calcium oxalate, the fine minerals composed of iron and magnesium observed here around the cells are also likely to be the consequence of biomineralization processes. The presence of Fe-rich diagenetic minerals and biogenic clays has been previously reported around

FIG. 3. Spatial distribution and vitality of endolithic lichen cells. A, CSLM 3-D image of an endolithic lichen from the Canada Glacier area (a, algal cells; f, fungal hyphae; ls, lithic substratum); B, SEM-BSE image of a deep fissure in a rock zone colonized by Lecidea cancriformis from Granite Harbour, black arrow denotes a narrow fissure occupied by fungal cells; C, SEM-BSE image showing Lecidea sp. mycobionts colonizing a narrow fissure in a rock from Granite Harbour. D, CSLM image of a cavity close to the surface colonized by an endolithic lichen from Canada Glacier. E \& F, CSLM images of a colony from the Canada Glacier area stained with the BacLight kit and then processed for CSLM; E, fissures showing the presence of a zone composed by dead hyphae (red arrows) in the proximity of other living algal cells (white arrows) and fungal cells (green arrows); F, fissure showing a mixture of living (white arrows) and dead (red arrows) photobiont cells. 

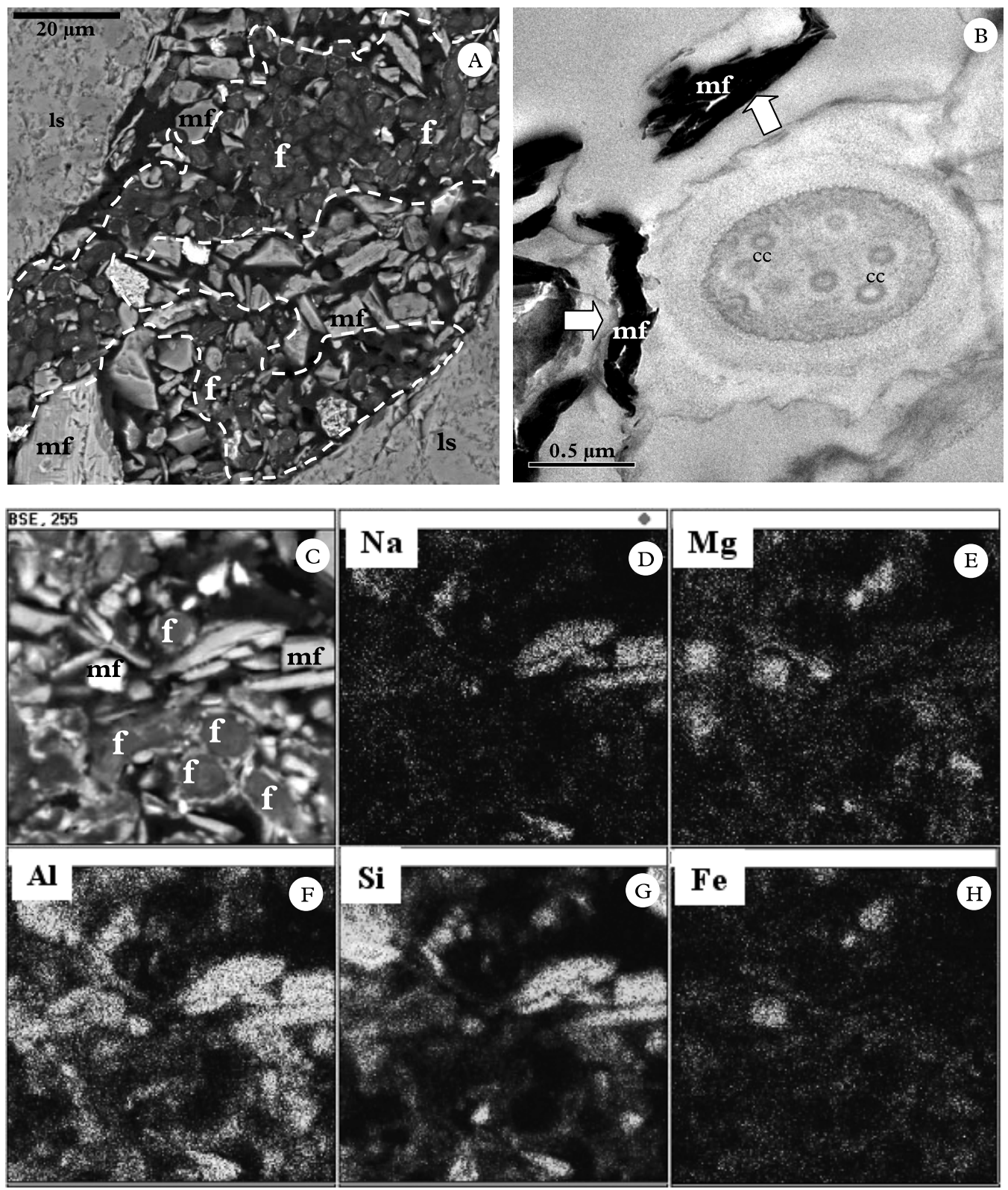
chasmoendolithic hyphae and bacterial cells (Wierzchos et al. 2003). Biomineralization processes are related to the local chemical composition of the substratum (Bjelland et al. 2002; De los Ríos et al. 2005) and can give rise to chemical microenvironments that could affect the establishment of another microorganism in the zone (De los Ríos et al. 2002). These processes may have physiological consequences: biogenic minerals have been found to completely envelope symbiont cells or to occupy a large proportion of the colonized area, suggesting these deposits could act as a barrier against the exchange of nutrients and affect nutrient cycling in the biofilm. The 'fossilized' cells described in endolithic systems could be the result of these interactive processes rather than a change in the external habitat as has been suggested (Friedmann et al. 1994). In the present work mycobiont cells were found to be covered by EPS closely associated with mineral fragments, suggesting a certain level of interaction of these compounds with rock components and their possible involvement in the detected biogeochemical processes (Barker \& Banfield 1996; Barker et al. 1998). The formation of extracellular microbial polymeric layers may be controlled not only by nutrient availability, but also by the availability of metal ions to which the cell is exposed (Bevereidge 1989; Ferris 2000).

For the first time, we have been able to analyse the physiological state of symbiont cells in situ, without removing the biofilm from the lithic substratum. This allows the precise detection and localization of living and dead cells within the lithic susbtratum. It was found that mycobiont and photobiont cells in different physiological states were intermixed, and that the majority of cells were viable. This confirms the results of a previous study (De los Ríos et al. 2004) that explored the physiological state of different endolithic microorganisms in biofilms. Such a high proportion of viable cells might indicate that these systems are very young and little dead material has yet accumulated, or that they are very old and long-lived with a very low productivity and very long-lived cells. At present we cannot answer this question. Some endolithic systems have been shown to be very old, even thousands of years (Johnston \& Vestal 1991; Sun \& Friedmann 1999) but dates of more samples are needed in order to make any generalizations. Few studies have assessed productivity on any time scale although it is suspected that productivity of endoliths is lower than that of epilithic lichens. The results of Friedmann et al. (1993), derived from cryptoendolithic communities, suggest that net ecosystem productivity from long-term events is only about $3 \mathrm{mg} \mathrm{C} \mathrm{m}^{-2} \mathrm{y}^{-1}$.

The biological success of these endolithic lichens requires the development of life strategies that will allow them to maintain their populations in this extreme habitat over a period of time (Block 1994). The survival of endolithic lichens in continental Antarctica might be more a question of avoiding rather than tolerating the extreme conditions outside the microhabitat (Friedmann 1982; Friedmann et al. 1993; De los Ríos et al. 2003; Cowan \& Tow 2004). Production of EPS is a survival mechanism and the matrix is thought to be one of the key biofilm components involved in the protection of the component microorganisms from the environment (Davey \& O'Toole 2000; De los Ríos et al. 2004). Extracellular polymeric substances are able to form microenvironments with conditions different from those of the bulk in terms of radiation received, capacity of water retention and $\mathrm{pH}$, among other factors, which could favour the

\footnotetext{
FIG. 4. Mineral components of biofilms containing endolithic lichens. A, SEM-BSE image of a fissure colonized by mycobiont cells from Granite Harbour, dashed line outlines the part of the fissure occupied by mycobiont cells (a, algal cells; f, fungal hyphae; ls, lithic substratum, mf, mineral fragments); B, TEM image of an endolithic mycobiont cell of a non-identified lichen from Taylor Valley in the proximity of clay mineral fragments (arrows), note the fungal cells with several concentric bodies (cc); C-H, element distributions visualized by EDS in a fissure of a rock from Granite Harbour colonized by mycobiont cells of Lecidea sp.; C, SEM-BSE image; D, Na; E, Mg; F, Al; G, Si; H, Fe.
} 

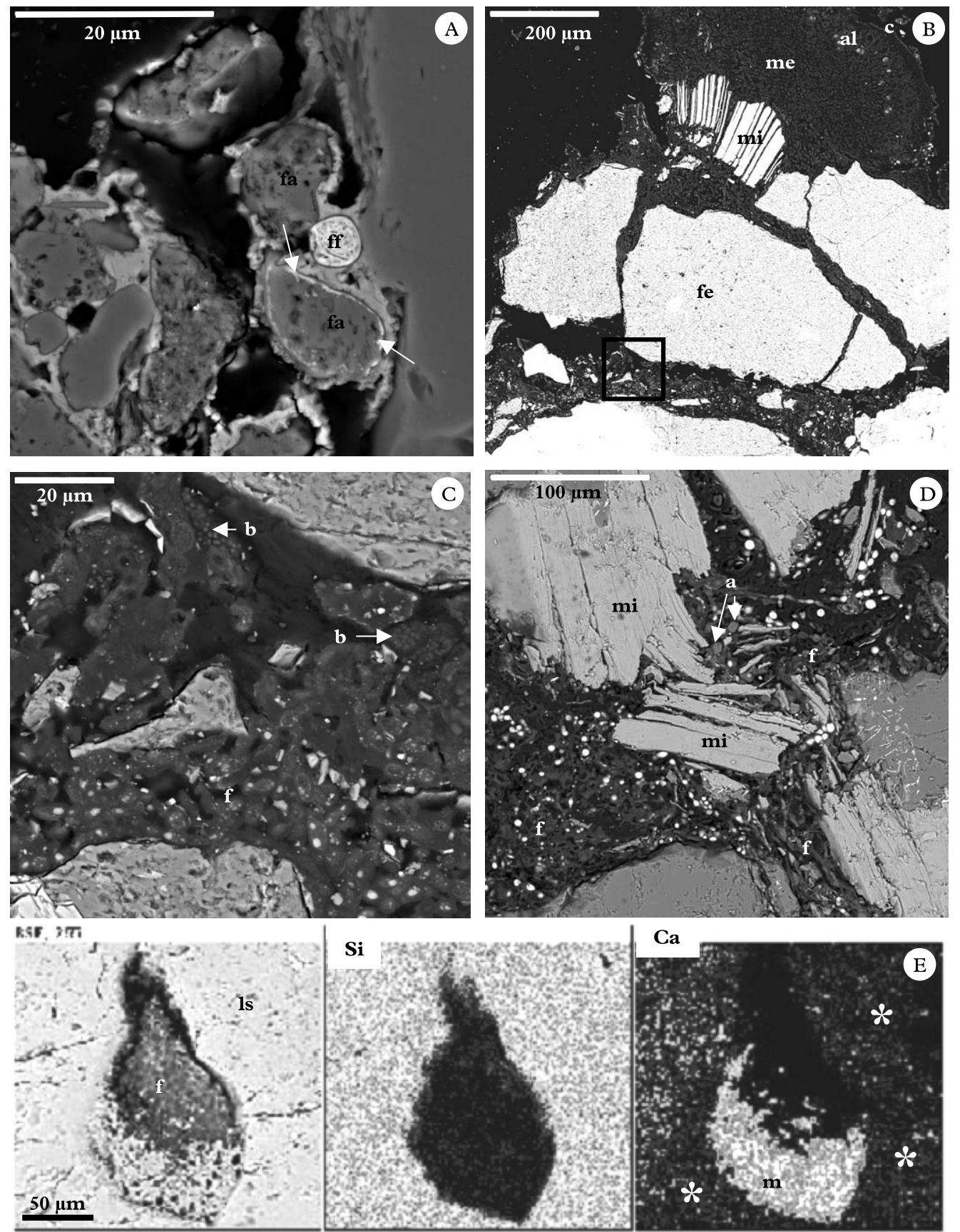

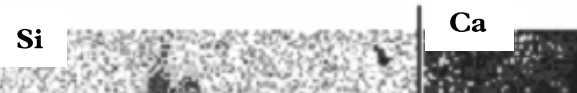

E

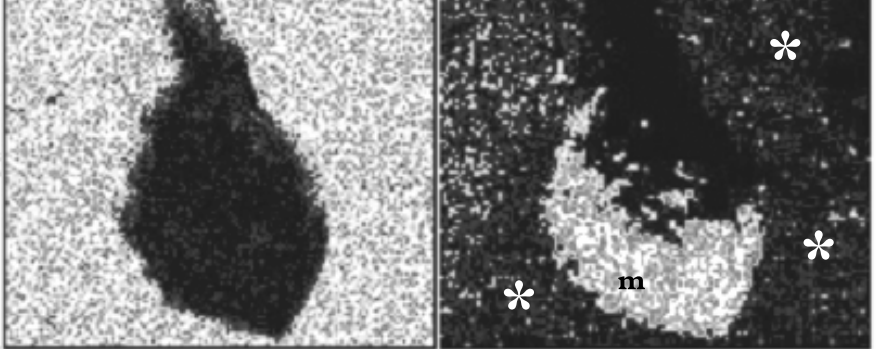


survival of lithobionts (De los Ríos et al. 2003). In addition, EPS can be considered long-term accumulators of carbon and energy (Wolfaardt et al. 1999) and are thus of great interest in terms of adaptation to Antarctic conditions. The endolithic strategy is also closely linked to the interactions of the lichen symbiont cells with the lithic substrata (Johnston \& Vestal 1993). Interactions between the components of the biofilms and their substrates determine the existence of different microhabitats and chemical microenvironments in these lithic microecosystems (Bungartz et al. 2004; De los Ríos et al. 2002, 2003). The spatially close association of endolithic symbiont cells with the lithic substratum, and the alteration of bedrock minerals and synthesis of biominerals observed in the antarctic granite analyzed, also supports this hypothesis.

Whilst lichen biogeochemical activity can limit the bioavailability of some metals, it can also release other nutrients to the microecosystem; the present study is an example of how endolithic lichens can actively contribute to the mineral cycling (Wierzchos \& Ascaso 1996, 1998). It is known that lichens occupy extensive areas in the world, but this area is much greater if endolithic growth forms are also included in such global estimates. This means their global contribution to biogeochemical cycles both through mineral cycling and metabolic activity might need to be re-assessed.

The authors thank Fernando Pinto, Charo Santos and Sara Paniagua for technical assistance and Ana Burton for reviewing the English. This study was funded by grants REN2003-07366-C01/C02 and BOS200302418 of the Plan Nacional I+D.

\section{REFERENCES}

Aghamiri, R. \& Schwartzman, D. W. (2002) Weathering rates of bedrock by lichens: a mini watershed study. Chemical Geology 188: 249-259.

Ascaso, C. \& Wierzchos, J. (2003) The search for biomarkers and microbial fossils in Antarctic rock microhabitats. Geomicrobiology fournal 20: 439450.

Banfield, J. F., Barker, W. W., Welch, S. A. \& Taunton, A. (1999) Biological impact on mineral dissolution: application of the lichen model to understand mineral weathering in the rizosphere. Proceedings of the National Academy of Sciences 96: 3404-3411.

Barker, W. W. \& Banfield, J. F. (1996) Biologically versus inorganically mediated weathering reactions: relationship between minerals and extracellular microbial polymers in lithobiontic communities. Chemical Geology 132: 55-69.

Barker, W. W., Welch, S. A., Chu, S. \& Banfield, J. F. (1998) Experimental observations of the effects of bacteria on aluminiosilicate weathering. American Mineralogist 83: 1551-1563.

Beveridge, T. J. (1989) Role of cellular design in bacterial metal accumulation and mineralization. Annual Review of Microbiology 43: 147-171.

Bjelland, T., Saebo, L. \& Thorseth, I. H. (2002) The occurrence of biomineralization products in four lichen species growing on sandstone in western Norway. Lichenologist 34: 429-440.

Bjelland, T. \& Thorseth, I. H. (2002) Comparative studies of the lichen-rock interface of four lichens in Vingen, western Norway. Chemical Geology 192: 81-98.

Block, W. (1994) Terrestrial ecosystems: Antarctica. Polar Biology 14: 293-300.

Bungartz, F., Nash III, T. H. \& Ryan, B. D. (2004) Morphology and anatomy of chasmolithic versus epilithic growth: a taxonomic revision of inconspicuous saxicolous Buellia species from the Sonoran Desert Region generally ascribed to the "Buellia punctata" group. Canadian fournal of Botany 82: 540-562.

Castello, M. \& Nimis, P. L. (1997) Diversity of lichens in Antarctica. In Antarctic communities. Species, structure and survival (B. Battaglia, J. Valencia \& D. W. H. Walton, eds.): 15-21. Cambridge: Cambridge University Press.

FIG. 5. Electron micrographs of Antarctic endolithic and epilithic lichens. A, SEM-BSE image of fossilized (mineralized) photobiont (fa) and mycobiont (ff) cells occupying a pore in sandstone rock from Mount Fleming, arrows point to a mineralized algal cell wall with large amounts of iron; B, SEM-BSE image of the interface made by a Buellia frigida thallus and the surface of a Granite Harbour rock (c, upper cortex; al, algal layer; me, medulla; mi, mica; fe, feldspar); C, SEM-BSE image of the boxed area in Fig. 5B where bacterial (b) and fungal (f) cells intermix under an epilithic lichen; D, endolithic fungal growth in a rock from Granite Harbour causing the detachment and separation of mica layers (mi) (a, algal cells; f, fungal hyphae); E, SEM-BSE and EDS element distribution maps of a rock (Granite Harbour) zone colonized by mycobiont cells (f) of Lecidea cancriformis showing areas of plagioclase substratum with different amounts of calcium, suggesting the depletion of this element

(asterisks), and calcium rich mineral deposits $(\mathrm{m})$ which could correspond to calcium oxalate accumulation. 
Cooks, J. \& Otto, E. (1990) The weathering effects of the lichen Lecidea aff. Sarcogynoides (Koerb.) on magaliesberg quartzite. Earth Surface Processes and Landforms 15: 491-500.

Cowan, D. A. \& Tow, L. A. (2004) Endangered Antarctic environments. Annual Review of Microbiology 58: 649-690.

Davey, M. E. \& O'Toole, G. A. (2000) Microbial Biofilms: from ecology to molecular genetics. Microbiology and Molecular Biology Reviews 64: 847-867.

De los Ríos, A., Ascaso, C. and Wierzchos, J. (1999) Study of lichens with different state of hydration by the combination of low temperature sacnning electronand confocal laser scanning microscopies. International Microbiology 2: 251-257.

De los Ríos, A. \& Ascaso, C. (2001) Preparative techniques for transmission electron microscopy and confocal laser scanning microscopy of lichens. In Protocols in Lichenology (I. Kranner \& R. P. Beckett \& A. K. Varma, eds.): 87-151. Berlin: Springer.

De los Ríos, A., Wierzchos, J. \& Ascaso, C. (2002) Microhabitats and chemical microenvironments under saxicolous lichens growing on granite. Microbial Ecology 43: 181-188.

De los Ríos, A., Wierzchos, J., Sancho, L. G. \& Ascaso, C. (2003) Acid microenvironments in microbial biofilms of Antarctic endolithic microecosystems. Environmental microbiology 5: 231-237.

De los Ríos, A., Wierzchos, J., Sancho, L. G. \& Ascaso, C. (2004) Exploring the physiological state of continental Antarctic endolithic microorganisms by microscopy. FEMS Microbiology Ecology 50: 143-152.

De los Ríos, A., Sancho, L. G., Grube, M., Wierzchos, J. \& Ascaso, C. (2005) Endolithic growth of two Lecidea lichens in granite from continental Antarctica detected by molecular and microscopy techniques. New Phytologist 165: 181-190.

Ferris, F. G. (2000). Microbe-metal interactions in sediments. In Microbial Sediments (R. E. Riding \& S. M. Awramik, eds): 121-126. Berlin: SpringerVerlag.

Friedmann, E. I. (1982) Endolithic microorganisms in the Antarctic cold desert. Science 215: 1045-1053.

Friedmann, E. I. \& Ocampo-Friedmann, R. (1984). Endolithic microorganisms in extreme dry environments: analysis of a lithobiontic microbial habitat. In Current Perspectives in Microbial Ecology Vol. XII (M. J. Klug \& C. A. Reddy, eds.): 177-185. Washington, D.C.: American Society for Microbiology.

Friedmann, E. I., Kappen, L., Meyer, M. A. \& Nienow, J. A. (1993). Long-term productivity in the cryptoendolithic microbial community of the Ross Desert, Antarctica. Microbial Ecology 25: 51-69.

Friedmann, E. I., Druk, A. Y. \& Mckay, C. P. (1994) Limits of life and microbial extinction in the Antarctic desert. Antarctic Fournal of USA 29:176179.
Golubic, S., Friedmann, I. \& Schneider, J. (1981) The lithobiontic ecological niche, with special reference to microorganisms. Fournal of Sedimentary Petrology 51: 475-478.

Green, T. G. A., Schroeter, B. \& Sancho, L. G. (1999) Plant life in Antarctica. In Handbook of Functional Plant Ecology (F. I. Pugnaire \& F. Valladares, eds.): 495-543. New York, Basel: Marcel Dekker, Inc.

Johnston, C. G. \& Vestal, R. (1991) Photosynthetic carbon incorporation and turnover in Antarctic cryptoendolithic microbial communities: are they the slowest growing communities on earth? Applied and Environmental Microbiology 57: 2308-2311.

Johnston, C. G. \& Vestal, R. (1993) Biogeochemistry of oxalate in the Antarctic cryptoendolithic lichen-dominated community. Microbial Ecology 25: 305-319.

Matthes, U., Turner, S. J. \& Larson, D. W. (2001) Light attenuation by limestone rock and its constraint on the depth distribution of endolithic algae and cyanobacteria. International fournal of Plant Sciences 162: 263-270.

Øvstedal, D. O. \& Lewis-Smith, R. I. (2001) Lichens of Antarctica and South Georgia: A Guide to Their Identification and Ecology. Cambridge: Cambridge University Press.

Reynolds, S. (1963) The use of lead citrate at high $\mathrm{pH}$ as an electron-opaque stain in electron microscopy. Fournal of Cell Biology 17: 200-211.

Robinson, S. A., Wasley, J., \& Tobin, A. K. (2003) Living on the edge - plants and global change in continental and maritime Antarctica. Global Change Biology 9: 1681-1717.

Seppelt, R. D., Green, T. G. A. \& Schroeter, B. (1995) Lichens and mosses from the Kar Plateau, Southern Victoria Land, Antarctica. New Zealand fournal of Botany 33: 203-220.

Sterflinger, K. (2000) Fungi as geologic agents. Geomicrobiology fournal, 17: 97-124.

Sun, H. J. \& Friedmann, E. I. (1999) Growth on geological time scales in the Antarctic crytoendolithic microbial community. Geomicrobiology fournal 16:193-202.

Wierzchos, J. \& Ascaso, C. (1994) Application of back-scattered electron imaging to the study of the lichen rock interface. Fournal of Microscopy 175: 54-59.

Wierzchos, J. \& Ascaso, C. (1996) Morphological and chemical features of bioweathered granitic biotite induced by lichen activity. Clays and Clay Minerals 44: 652-657.

Wierzchos, J. \& Ascaso, C. (1998) Mineralogical transformation of bioweathered granitic biotite, studied by HRTEM: evidence for a new pathway in lichen activity. Clays and Clay Minerals 46: 446-452.

Wierzchos, J. \& Ascaso, C. (2001) Life, decay and fossilisation of endolithic microorganisms from the Ross Desert, Antarctica: suggestions for in situ further research. Polar Biology 24: 863-868.

Wierzchos, J., Ascaso, C., Sancho, L. G. \& Green, A. (2003) Iron-rich diagenetic minerals are bio- 
markers of microbial activity in Antarctic rocks. Wolfaardt, G. M., Lawrence, J. R. \& Korber, D. R. Geomicrobiology fournal 20: 15-24.

Wierzchos, J., de los Rios, A., Sancho, L. G. \& Ascaso, C. (2004) Viability of endolithic micro-organisms (1999) Function of EPS. In Microbial Extracellular in rocks from the McMurdo Dry Valleys of AntPolymeric Substances (J. Wingender, T. R. Neu and arctica established by confocal and fluorescence microscopy. Fournal of Microscopy 216: 57-61.

Accepted for publication 8 fuly 2005 